promover a já apontada e urgente disciplina ao setor do co-seguro, possibilitando à experiência prática amoldar-se aos cânones jurídicos que desenham o perfil do instituto como um contrato único de colaboração empresária, voltado à finalidade econômicosocial que lhe unanimemente é reconhecida. Esta é a inadiável tarefa a ser cometida aos órgãos do "Sistema do Seguro", que deverão considerar - implementando, no espaço regulamentar que lhes concerne , a diretriz da solidariedade social, de tão fundas raízes no Direito dos Seguros.
Porém, para tanto, dever-se-á levar em conta - e assim também os juízes, ao decidirem os casos - não apenas os princípios e regras do novo Código Civil e do Código de Defesa do Consumidor, mas, fundamentalmente, a idéia de "comunidade de interesses, esforços e fins" que subjaz e comanda o inteiro instituto do seguro, polarizando-a no interesse comum dos segurados, inconfundível com cada interesse isoladamente considerado.

Só assim, penso eu, poder-se-á, nesse espaco, fazer ouvir a voz da diretriz constitucional da solidariedade social, de tão fundas raízes no Direito dos Seguros.

\title{
O Direito Internacional e a sua Relação
}

\section{com o Direito Interno*}

\section{Leandro Leal Ghezzi}

Especialista em Direito da Economia e da Empresa pela FGV Mestrando em Direito Privado na UFRGS

\section{INTRODUÇÃO}

I.ODIREITOINTERNACIONAL

a) O Desenvolvimento Histórico do Direito Internacional.

b) O Caráter Jurídico do Direito Internacional.

\section{II.A RELAÇÃODODIREITOINTERNACIONALCOMODIREITOINTERNO}

a) As Teorias que Tratam da Relação.

b) Os Conflitos entre o Direito Internacional e o Direito Interno.

CONCLUSÃO

BIBLIOGRAFIA

\section{Introdução}

A cada dia que passa, o Direito internacional assume maior importância. Afinal, cabe a ele a difícil tarefa de pautar as relações que se estabelecem entre os diversos povos de nosso planeta, relações estas que são ao mesmo tempo causa e efeito do ritmo impressionante do desenvolvimento tecnológico e dos processos de integração econômica que hoje fazem parte de nossa realidade.
Parece, pois, relevante tratar do tema proposto, em que pese ser a sua importância subestimada por muitos, que, como teremos oportunidade de ver, negaram até mesmo a existência do Direito internacional. Certamente, assim agiram - e ainda há quem aja - por não perceber, ou por não querer admitir, a importância do Direito internacional e a sua presença cada vez maior em nossas vidas, regrando inúmeros fatos que são hoje corriqueiros para todos.

- Trabalho apresentado no curso de Mestrado em Direito da Universidade Federal do Rio Grande do Sul, disciplina de Teoria Geral do Direito, ministrada pelos Profs. Drs. Cezar Saldanha Souza Júnior e Luís Fernando Barzotto 
Consideremos, por exemplo, uma viagem aérea internacional, um negócio jurídico de compra e venda celebrado entre pessoas residentes em países distintos - o que agora é ainda mais freqüente em razão do fenômeno da internet. Tenhamos em mente o número cada vez maior de tratados internacionais, dispondo sobre assuntos como estes e infinitos outros, sobre temas que se renovam e que são criados a cada dia que passa. Apenas isto já bastaria para justificar o presente estudo.

Nesse contexto, portanto, examinaremos inicialmente com maior atenção o objeto mais amplo deste trabalho, qual seja ele, o Direito internacional. Para tanto, elaboraremos uma breve resenha de sua evolução histórica e teceremos algumas considerações necessárias acerca do processo de sua construção dogmática e do seu questionado caráter jurídico.

Em uma segunda etapa, enfocaremos a questão específica da relação entre o Direito internacional e o Direito interno de cada país. Primeiro, veremos quais são as principais teorias que explicam esta relação e quem foram seus mais ilustres representantes. Depois, e por último, versaremos sobre a instigante questão dos conflitos que muitas vezes se estabelecem entre as normas do Direito internacional e aquelas do Direito interno, para o que contaremos com o valioso auxílio do Direito comparado.

Ao final, com base nos elementos colhidos no curso de nosso estudo, apresentaremos algumas conclusões sobre o tema proposto. Esperamos, então, ter compreendido melhor o que é o Direito internacional e como ele se relaciona com o Direito interno da cada país e, especialmente, com o Direito brasileiro.

\section{O Direito Internacional}

\section{a) O Desenvolvimento Histórico do Direito} Internaciona

Inicialmente, parece relevante tecer breves considerações sobre o processo de desenvolvimento histórico do Direito Internacional. Isto na medida em que análise desta natureza não apenas revelam a origem de importantes legados que a história nos deixou, mas também fornecem elementos vitais para a adequada compreensão do objeto estudado, neste caso o Direito internacional.

Segundo Carlos Alberto Bittar Filho, os primeiros elementos para o surgimento do Direito internacional já se faziam presentes em alguns âmbitos culturais da Idade Antiga. Datam desta época os tratados mais antigos de que se tem notícia e já então se praticava a diplomacia ${ }^{1}$.

A primeira contribuição efetiva para o desenvolvimento do Direito internacional, no entanto, remonta à Idade Média. Trata-se da concepção de unidade do gênero humano ${ }^{2}$. Outrossim, as idéias de igualdade e de fraternidade universais defendidas pelo cristianismo e propagadas pelas obras de Santo Agostinho e São Tomás de Aquino fizeram com que se passasse a compreender que havia princípios jurídicos que obrigavam não só os indivíduos, mas também os Estados ${ }^{3}$.

1 BITTAR Filho, Carlos Alberto. "Evolução Histórica do Direito Internacional" in Revista de Informação Legislativa, $\mathrm{n}^{\circ} 115$, Julho-Setembro 1992, p. 385. No mesmo sentido, VERDROSS, Alfred. Derecho Internacional Publico. Madrid: Aguilar, 1957, p. 37.

BITTAR Filho, Carlos Alberto. Op. cit., p. 387. Michel Villey antecipa esta percepcão, afirmando que "La pensée biblique et la grecque avaient conscience qu' il existe une communauté de l'humanité tout entière" ("Considérations Intempestives sur le Droit des Gens" in Archives de Philosophie du Droit, Tome 32. Paris: Sirey, 1987, p. 14).

${ }^{3}$ Cf. Alfred Verdross, op. cit., p. 38.

Revista da Faculdade de Direito da UFRGS, v. 21, Março/2002
De qualquer forma, foi apenas no início da Idade Moderna que o Direito internacional adquiriu contornos de disciplina autônoma. Contribuíram para isto a descoberta da América, que fez necessário definir qual Direito era aplicável às relações entre os nativos e os colonizadores, e as obras de Francisco de Vitória (De Legibus ac Deo Legislatore, de 1613), Alberico Gentili (De Legationibus, de 1538) e Hugo Grocio (De Jure Belliac Pacis, de 1625) ${ }^{4}$.

Dentre estas obras, a mais importante foi a de Hugo Grocio. Por ter sido a primeira a sistematizar o Direito internacional, ela fez com que este jurista holandês passasse a ser considerado o fundador do direito internacional como ramo autônomo da ciência do Direito, ainda que alguns autores salientem que por ter sido Grocio fortemente influenciado pelos teólogos e juristas espanhóis, a autêntica origem da disciplina remontaria efetivamente à Escola (Relectiones Theologicae, de 1557), Francisco Soares Espanhola ${ }^{5}$.

Este primeiro período do Direito internacional moderno, como bem observa Alfred Verdross, não teve relevância meramente histórica. Isto porque, segundo este célebre jurista, foi nesta época que ocorreu também a constituição da comunidade de Estados ${ }^{6}$.

Uma segunda e importante etapa do Direito internacional moderno teve início como Tratado de Paz de Westphalia (1648) que, inspirado nas idéias de Grocio, encerrou a Guerra dos Trinta Anos. A partir de então, o sistema internacional passou a ser constituído por Estados independentes e soberanos, juridicamente iguais entre $\mathrm{si}^{7}$.

Com isto, um novo princípio instaurouse: o do equilíbrio entre os Estados. Alçado a princípio diretivo do direito internacional com a Paz de Utrecht (1713), ele estabelecia que Estado algum poderia tornar-se poderoso a ponto de, sozinho ou aliado, impor sua vontade aos demais 8 .

4 Cf. Carlos Alberto Bittar Filho, op. cit., pp. 388-9. O autor refere sucintamente o conteúdo de cada uma das obras: "Francisco de Vitória analisou, sob o prisma filosófico-teológico, a chegada dos espanhóis à América. Segundo ele, as relações entre os indígenas e os colonizadores deviam ser regidas por um direito que conviesse a toda a humanidade, o 'Direito das Gentes"; "Francisco Soares ... defendeu pertencerem as cidades independentes, as repúblicas e os reinos, a um conjunto maior, o gênero humano, regulado, consoante ele, por direito especial"; "Alberico Gentile estudou detidamente a questão das imunidades diplomáticas, sob o prisma puramente jurídico"; e "Hugo Grocio ... tratou do reconhecimento e da observância de normas que, conquanto pertencentes à comunidade global, eram, para ele, necessárias à solução de problemas de cada Estado".

${ }_{5}^{5}$ GOLDSCHMIDT, Werner. Introducción Filosófica al Derecho. Buenos Aires: Depalma, 1987, pp. 506 e 507.

- VERDROSS, Alfred. Op. cit., p. 39. Segundo o autor, esta comunidade de Estados apresentava originariamente as seguintes características: a) só eram sujeitos originários do direito internacional os Estados soberanos e a Sede Apostólica; b) não havia frgao legislatio central $e$ as normas do Direto intemacional surgam dos tatados $\mathrm{e}$ do costume; $\mathrm{c}$ ) não havia un je boa-fé se considerava prejudicado em seus direitos podia recorer ào cutogavelan a um acordo no lítgio, todo Estado que de boa-té se considerava prejudicado en sets dirtios polth recor

BITTAR Filho, Carlos Alberto. Op. cit., p. 390.

${ }^{8}$ VERDROSS, Alfred. Op. cit., p. 40. Segundo Verdross, os princípios diretivos da comunidade internacional deste período seriam os seguintes: a) os Estados são comunidades territoriais soberanas, que em seus territórios respectivos exercem o poder supremo e em princípio exclusivo; b) os Estados podem dispor entre si de seu território segundo as regras do direito privado; c) os Estados são independentes e iguais entre si; d) a comunidade internacional continua sendo desorganizada, carecendo de autoridade central; e) os Estados reconhecem as normas do direito internacional, mas cada um deles é que tem que decidir de boa-fé acerca de sua aplicação e interpretação; f) os Estados têm também o direito de impor através da autoutela (represálias ou guerra) seus direitos (direito da autoexecução); g) surge a concepşão de que todo o Estado tem $o$ direito de declarar guerra se assim exigirem seus interesses, superando-se, desta forma, a doutrina medieval do bellum justum; h) em caso de guerra, os Estado terceiros são livres para se unir a uma das partes beligerantes ou para permanecer neutros (pp. 40-41) 
É interessante observar também que com a colonização do Novo Mundo pelos europeus o Direito internacional experimentou um significativa ampliação do seu âmbito espacial de validade. Quanto aos sujeitos do Direito internacional, entretanto, o primeiro não europeu surgiu apenas com a separação da treze colônias americanas da Inglaterra em 1776 $\mathrm{Na}$ América Latina, o nascimento reconhecimento de novos sujeitos do Direito internacional veio a ocorrer em função do processos de independência das colônias espanholas e portuguesas nas primeiras décadas do século XIX. E, na segunda metade deste mesmo século, foram também reconhecidos de maneira geral como sujeito de Direito internacional os Estados asiáticos não cristãos (o império do Japão, a China e o Afeganistão, entre outros) ${ }^{9}$.

No período que se seguiu, houve um esforço crescente de institucionalização da ordem internacional. O relacionamento entre os Estados sofreu modificações, passando da política de mera coexistência para a de colaboração, e com a realização de importantes conferências internacionais (v.g., a Primeira e a Segunda Conferências de Paz de Haia, em 1899 e 1907, respectivamente), o Direito internacional fortaleceu-se em termos de positivação ${ }^{10}$

Neste contexto, o turbulento período histórico da Primeira Guerra Mundial e o desejo

9 VERDROSS, Alfred. Op. cit., pp. 44-45.

${ }^{10}$ Carlos Alberto Bittar Filho, op. cit., pp. 392 e 397. Alfred Verdross ressalta com precisão que os progressos realizados pelo Direito internacional positivo desde meados do século XIX foram favorecidos pelo estado de paz ininterrupto que desde 1871 reinou entre as grandes potências européias (op. cit., p. 43). O raciocínio inverso (a paz favorecida pelos progressos do Direito internacional positivo) também nos parece verdadeiro.

"Alfred Verdross, entretanto, refere que a Quádrupla Aliança, o primeiro ensaio de uma organização supraestatal, foi criada na Segunda Conferência de Paz de Paris, em 1815 (op. cit., p. 42)

${ }^{12}$ Cf. Alfred Verdross, op. cit., p. 41

${ }^{13}$ VERDROSS, Alfred. Op. cit., p. 50. Dentre os principais colaboradores deste intento devem ser citados Kelsen e o próprio Verdross.

Revista da Faculdade de Direito da UFRGS, v. 21, Março/2002

Tal ocorrência serve de marco para deliorganizado $^{12}$ tornou realmente universal. Foi também a partir comum de que episódios desta natureza não mais se repetissem serviram de estimulo para a ganização formal de uma comunidade interAssistiu-se, assim, ao nascimento da Sociedade das Nações, a primeira organização coríodo que a doutrina francesa costuma chamar do Direito internacional clássico. Com a criação da Sociedade das Nações

Segundo Verdross, foi apenas a partir momento, ou seja, depois da primeira guerra mundial, que o direito internacional se os conceitos formais fundamentais ou ategorias suscetíveis de apreender a matéria a unidade sistemática, desenvolvendo-se, Direito internacional ${ }^{13}$

Além disso, as limitações congênitas da Sociedade das Nações e a sua incapacidade de mostravam que o da Segunda Guerra mundipoderia ser alcançado por uma organização interestatal mais forte. Desta forma, em 1945 de cunho internacional ${ }^{11}$, tendo por objetivo a criou-se a Organização das Nações Unidas.

Para José Carlos de Magalhães, a insuficiência da ordem internacional baseada apenas nos Estados constatada com a Segunda Guerra mundial teria tornado necessário criar organizações, algumas de caráter supranacional, capazes de interferir nos poderes dos Estados, limitando-os e, portanto, delimitando competências, ou seja, delimitando o seu poder de declarar o Direito. Na sua visão, o surgimento de um número cada vez maior de organizações internacionais, de caráter universal ou regional, disciplinando a atuação dos Estados no plano interno e internacional, no período que se seguiu ao segundo conflito global teria tornado nítida a superação da noção de soberania dos Estados. Para este autor, portanto, deste momento em diante, a noção de soberania teria começado a ceder espaço para a noçã̃o de competência ${ }^{14}$.

O natural, nessa perspectiva, seria obviamente que os Estados cumprissem eles próprios a tarefa de delimitar seus poderes e atribuições. Infelizmente, no entanto, não podemos deixar de constatar que hoje em dia no âmbito econômico - senão em outros - os Estados enfrentam a concorrência dos grandes especuladores internacionais e das empresas multinacionais, os quais muitas vezes limitam a sua autoridade e condicionam as suas ações.

De qualquer forma, e não obstante esta realidade, é importante ressaltar que ao longo desse processo, ao homem foi atribuída a condição de protagonista neste cenário internacional. Realmente, como bem anota José
Carlos de Magalhães, “... tal reconhecimento cosfera internacional, não apenas como aspiração doutrinária, mas como norma de direito dotada de universalidade, para ser observada por todos os países". E ele arremata: "o reconhecimento da imperatividade do respeito aos direitos humanos, provindo da das ordens jurídicas nacionais aos princípios e valores nela consagrados. A ordem jurídica nacional, dissociada de tais valores, está condenada (...) a sucumbir, vendo-se compelida a eles adequar-se, mais cedo ou mais tarde" 15 .

Isto nos remete desde já à questão da relação do Direito internacional como o Direito interno. Mas, antes de passarmos a ela e até como uma condição para fazê-lo, é oportuno que enfoquemos, no contexto até aqui apresentado, o processo de construção dogmática do Direito internacional e, principalmente, a questão do seu caráter jurídico.

\section{b) O Caráter Jurídico do Direito Internacional}

Segundo Werner Goldschmidt, a efetiva existência de um Direito internacional pressupõe as seguintes condições: 1) Estados independentes que respeitem a independência dos demais; e 2) relações econômicas e culturais entre eles, íntimas o suficiente para fazer necessária uma regulamentação jurídica ${ }^{16}$. existiam estas duas condições. Havia, quanto muito, um Direito internacional embrionário, que, ao invés de se desenvolver, perdeu-se, em comunidade internacional, importa em sujeição

Como vimos, na Antigüidade não

${ }^{14}$ MAGALHÃES, José Carlos de. "Dos Fatores de Transformação do Direito Internacional" in Revista dos Tribunais, $\mathbf{n}^{\circ} 717$, Julho 1995 , p. 318

${ }^{15}$ MAGALHÃES, José Carlos de. Op. cit., pp. 318 e 319. Carlos Alberto Bittar Filho também identifica este fenômeno e acrescenta ainda a preocupação com o meio ambiente (op. cit., p. 396).

${ }^{16}$ GOLDSCHMIDT, Werner. Op. Cit., p. 505. 
função do surgimento do império romano, que abarcou praticamente todo o mundo até então conhecido. E, ao longo da Idade Média, esta situação não se alterou ${ }^{17}$.

Na verdade, foi apenas no século XVI, quando surgiram os Estados independentes, que as duas condições acima referidas para a existência do Direito internacional se fizeram presentes pela primeira vez ${ }^{18}$. Não por acaso foi que, também neste mesmo período, como já referimos, nasceu a ciência que se ocupa do seu estudo, iniciando-se o processo de sua construção dogmática e passando-se a indagar acerca do seu efetivo caráter jurídico.

Conforme Goldschmidt, os pioneiros Francisco de Vitória (1480-1546) e Francisco Suárez (1548-1617), entre outros, individualizaram o Direito internacional como um Direito entre Estados, diferente, ainda que dependente, do Direito Natural ${ }^{19}$. Para Alfred Verdross, contudo, o método da escola espanhola "parte de la filosofia social aristotélica y tomista, que viera en el hombre un ser racional y social (" animal rationale et sociale") por naturaleza, deduciendo de ello

${ }^{17}$ GOLDSCHMIDT, Werner. Op. Cit., p. 506.

${ }^{18}$ GOLDSCHMIDT, Werner. Op. Cit., loc. cit.. O autor salienta que foi neste mesmo século que Maquiavel cunhou

o termo "Estado" e Bodin o conceito de "soberania".

${ }^{19}$ GOLDSCHMIDT, Werner. Op. Cit., loc. cit..

${ }^{20}$ VERDROSS, Alfred. Op. cit., pp. 52-53. Celso D. de Albuquerque Mello tem este mesmo entendimento (Curso de Direito Internacional Público. Rio de Janeiro: Livraria Freitas Bastos, $2^{\mathrm{a}}$ edição, p. 60).

${ }^{21}$ VERDROSS, Alfred. $O p$. cit, p. 55. Neste sentido, ́́ intersente lem Direito natural e do Direito positivo no pensamento dos jusnaturalistas dos éśculos XVII e XVIII. Diz Bobbio acerca do Direeto natural e do Direito positivo no pensamento dos jusnaturalistas dos séculos XVII e XVIII. Diz Bobbio: "A mais
célebre distinção entre direito natural e direito positivo no pensamento moderno é devida a Grócio (considerado o pai do direito internacional) que em seu De jure belli ac pacis $(1,10)$ formula tal distinção em termos de jus naturale e $j u$ voluntarium: 'O direito natural é um ditame da justa razão destinado a mostrar que un ato é moralmente torpe o moralmente necessário segundo seja ou näo conforme à própria natureza racional do homem e e moratrar que tal ato é em consequiência disto vetado ou comandado por Deus, enquanto autor da natureza'. E acrescenta: 'Os atos relativamente aos quais existe un tal ditame da justa razão são oubrigatórios ou ilicitos por si mesmos" (O Positivismo Jurílico - Liçōes de Filosofia do Direito. São Paulo, Ícone, 1995, p. 20).

22 VERDROSS, Alfred. Op. cit., pp. 55 e 56 . O autor avança na questão, dizendo que para o jusnaturalismo puro, o Direito internacional se reduz a meras máximas da razão; os Estados vivem em estado de natureza e não é reconhecido aos tratados nem ao costume o valor de fontes jurídicas. Para Hobbes (1588-1679), neste estado de natureza reinaria, em princípio, a guerra de todos contra todos, ao passo que para Pufendorf (1632-1694) este
estado de natureza seria, ao contrário, pacífico. Por outro lado, o positivismo jurídico considera o Direito estado de natureza seria, ao contrário, pacífico. Por outro lado, o positivismo jurídico considera o Direito
internacional como mero produto da vontade. Segundo Johan Jakob Moser (1701-1785), a ciência do Direito internacional como mero produto da vontade. Segundo Johan Jakob Moser (1701-1785), a ciência do Direito
internacional não teria que perguntar como devem comportar-se entre si os Estados, mas sim dizer quais regras internacional não teria que perguntar como devem comportar-se entre si os Estados, mas sim dizer quais regras eles observam de fato em suas relações (pp. 57-59).

Revista da Faculdade de Direito da UFRGS, v. 21, Março/2002 concepções ao dizer que "no correr do século XVI, o Direito Internacional Público fo analisado e considerado sob a luz do jusnaturalismo e, dos séculos XVII ao XIX, sob o prisma da concepção positivista" ${ }^{23}$.

Entretanto, apesar de todo o esforço empreendido na construção dogmática do Direito internacional, a sua comparação com o Direito interno e as inevitáveis diferenças assim constatadas levaram muitos autores a negarlhe caráter jurídico. No entendimento de Werner Goldschmidt, os principais argumentos da "tese negativa do caráter jurídico do Direit internacional" seriam os seguintes: a) no Direito internacional, a maior parte das normas eman de convenções e são normas individuais; por tal razão, a ordem jurídica internacional contém inúmeros vazios. Além disso, não existe nenhum legislador preestabelecido. Por fim, se um do países interessados deseja alterar o Direito existente e não consegue o consentimento do demais países interessados, uma modificação pacífica se torna irrealizável; b) em relação ao Poder Executivo, ele existe dentro de cada paí e impõe a observância das leis porque tem um poder irresistível. A comunidade internacional, contudo, não conseguiu ainda organizar um Poder Executivo; ela não conhece senão constelações de forças, que às vezes não têm poder de impor um princípio jurídico, às vezes não têm interesse algum em fazê-lo; e finalmente, c) no Direito Internacional, como os juizes são nacionais de algum Estado, é difícil que eles não sejam parciais ${ }^{24}$.

${ }^{23}$ MAGALHÃES, José Carlos de. Op. cit., p. 397

${ }^{24}$ GOLDSCHMIDT, Werner. Op. Cit., pp. 508 e 509.

${ }^{25}$ VERDROSS, Alfred. Op. cit., p. 61.

${ }^{26}$ VERDROSS, Alfred. Op. cit., loc. cit.. José Inácio G. Franceschini refere que para Espinosa o Estado, investido de parte do poder divino, seria superior aos acordos internacionais, deles podendo livrar-se na medida de seus ores" in Revista dos Tribunais, $\mathrm{n}^{\circ}$ 556, Fevereiro 1982, p. 28).

Revista da Faculdade de Direito da UFRGS, v. 21, Março/2002
Verdross também identifica estes "negadores do Direito internacional". São aqueles que, sem negar a existência do Direito Internacional, não reconhecem, contudo, o seu caráter jurídico, por entenderem que " $e$ conjunto de normas llamado 'derecho internacional' carece de legislador permanente, de un tribunal propriamente dicho y de um poder coercitivo central" ${ }^{25}$.

Os negadores partem, pois, do princípio de que a organização de uma comunidade - no caso, a internacional - só pode ser realizada por um poder que seja superior aos seus membros. Para eles, deve haver sempre e necessariamente uma relação de subordinação entre os membros desta comunidade e aquele poder superior. Hobbes, por exemplo, já afirmava que os Estados viviam em "estado de natureza", não estando submetidos a uma civitas maxima superior. E, como o direito positivo só poderia ser estabelecido por uma autoridade superior, não haveria Direito internacional positivo. Aquilo que entendemos por Direito internacional seriam meras palavras, que por falta de um poder coercitivo supraestatal não seriam capazes de dar segurança alguma. Espinosa também entendia assim. Para ele, apenas os Estados teriam poder coercitivo, carecendo o Direito internacional de uma base própria de poder $^{26}$.

Contudo, segundo Alfred Verdross, a negação mais radical do Direito internacional, seria a patrocinada pelos neohegelianos, principalmente Lasson e Binder. Isto por 
considerarem eles o Estado como a suprema organização humana ${ }^{27}$

O curioso, não obstante, é que o próprio Hegel considerava o Direito internacional como Direito. Na verdade, para Hegel, o Estado teria vontade absoluta, estando acima dos tratados internacionais por ele mesmo concluídos ${ }^{28}$ e 0 Direito internacional, em virtude da ausência de um poder supraestatal, se reduziria a um mero "Direito estatal externo". Assim, o ponto de contato entre a visão hegeliana do Direito internacional e a de Hobbes e Espinosa, se dá pelo argumento do poder, ou seja, por também ele entender que um autêntico Direito internacional só seria possível sobre a base de um poder supraestatal ${ }^{29}$.

Naturalmente, os argumentos erguidos pelos negadores do caráter jurídico do Direito internacional foram derrubados por seus defensores. Desta forma, impõe-se fazer menção, ainda que brevemente, aos contra-argumentos que para tanto foram utilizados.

Mais recentemente, Goldschmidt se encarregou de demonstrar a insubsistência da tese de que por não possuir os três poderes devidamente constituídos o Direito internacional seria destituído de caráter jurídico. No entendimento deste jurista, os principais argumentos da "tese negativa do caráter jurídico do Direito Internacional Público", podem ser rebatidos com base nas seguintes considerações: a) o Direito internacional não conhece apenas normas individuais, mas também numerosas normas gerais, as quais se encontram não apenas nas convenções, mas também no costume internacional. De outra parte, apesar da inexistência de um pode legislador plenamente desenvolvido, há nas Nações Unidas - e havia antes na Sociedade de Nações - um poder legislativo incipiente Por fim, mesmo independentemente destas organizações, sempre foi possível alterar as normas de Direito internacional pacificamente, quer mediante o costume internacional, quer po meio de convenções internacionais; b) quanto à questão do Poder Executivo, observa-se que mesmo no âmbito interno, ele apenas procura fazer com que se respeite as leis, mas de forma alguma sua força é irresistível. Ademais, no campo do Direito internacional existem muitas normas consuetudinárias e convencionais, principalmente sobre temas cotidianos, que são espontaneamente cumpridas. Na verdade, as normas de Direito internacional estão expostas à infidelidade como quaisquer outras; e c) a parcialidade ou imparcialidade judicial não é obstáculo para o funcionamento satisfatório da justiça arbitral ad hoc ou institucional em assuntos cotidianos ${ }^{30}$.

Jean Combacau, também marcha nesta mesma direção. Este autor, ao perquirir se o Direito internacional é apenas um agregado de elementos reunidos ao acaso ou um conjunto organizado em um sistema, acolhe esta segunda alternativa, por entender que o Direito internacional é uma ordem jurídica formalmente coerente, capaz de articular condutas efetivas
${ }^{27}$ VERDROSS, Alfred. Op. cit. p. 62. Conforme Celso D. de Albuquerque Mello: "Adolf Lasson reduz o DI a uma simples relação de força, uma vez que o Estado, sendo um fim em si mesmo, não poderia existir qualquer sistema normativo superior a ele" e "Júlio Binder considera que não existe DI, porque não existe uma comunidade p. cit., pp. 39 e 40)

${ }^{28}$ FRANCESCHINI, José Inácio G.. Op. cit., loc. cit.

${ }^{29}$ VERDROSS, Alfred. Op. cit., pp. 62-63.

${ }^{30}$ GOLDSCHMIDT, Werner. Op. Cit., pp. 509, 510 e 523 .

Revista da Faculdade de Direito da UFRGS, v. 21, Março/2002 dos sujeitos de suas relações normativas e animada por uma lógica global ${ }^{31}$.

Muito antes de Goldschmidt e de Combacau, Alfred Verdross já rebatia o argumento de que não haveria um Direito internacional pela ausência de um poder supraestatal afirmando que uma comunidade pode criar-se não apenas por uma autoridade central, mas também pela cooperação dos consortes jurídicos, sobre a base de convicções jurídicas comuns, e ser garantida através de um certo equilíbrio de forças. Este tipo de estrutura se denominaria, diferentemente do Direito de subordinação ou fundado no senhorio, Direito de coordenação ou Direito corporativo. Também o Direito de coordenação estaria "sobre" os consortes jurídicos, visto que as normas estabelecidas de comum acordo seriam para estes tão obrigatórias quanto as normas do Direito de subordinação. Estes tipos jurídicos, aliás, só se diferenciariam na medida em que o Direito de subordinação possuiria órgãos centrais de criação e execução do direito, enquanto que no Direito de coordenação o processo de criação exigiria em todos os seus graus uma cooperação dos consortes jurídicos. Assim, ter-se-ia apenas que o Direito corporativo seria mais sensível do que o direito fundado no senhorio, dado que este disporia de meios coercitivos centrais, enquanto aquele seria impotente sem a cooperação dos consortes jurídicos ${ }^{32}$.
O que ocorre, segundo Verdross, é que os negadores do Direito internacional esquecem que ele não é um sistema jurídico independente e hermético. Na verdade, na medida em que ele só pode ser cumprido e realizado pelo Direito estatal, a sua natureza não pode ser determinada isoladamente, mas sim "ha de aprehenderse em el marco del derecho positivo em su conjunto, cuya corona es el DI [Direito internacional]"33. Nesta mesma direção se conduziu o pensamento de Hans Kelsen, ainda que por caminho distinto. Senão, vejamos.

Na ótica da Teoria Pura do Direito de Kelsen, o Direito internacional é Direito na medida em que seja uma ordem coercitiva da conduta humana, tida como soberana, ligando aos fatos por ele definidos como pressupostos atos de coerção por ele determinados como conseqüências, e que possa, portanto, ser descrito em proposições jurídicas, da mesma forma que o Direito interno. A questão central para Kelsen é, pois, saber se o Direito Internacional estatui ou não atos coercivos como sanções ${ }^{34}$.

A conclusão de Kelsen é de que a guerra e as represálias são as sanções do Direito Internacional, não se distinguindo elas das sanções do Direito interno quanto ao seu conteúdo, mas apenas por se dirigirem contra $o$ Estado, ao qual pertencem os indivíduos que as sofrem efetivamente. Destarte, para o grande

${ }^{31}$ COMBACAU, Jean. "Le Droit Internacional: Bric-à-Brac ou Système?" in Archives de Philosophie du Droit Tome 31. Paris: Sirey, 1986, p. 85. Nas palavras do autor: "Envisagé abstraitement, c'est-à-dire comme animé seulement par le lien de validité formelle qui unit ses éléments, le droit international manifeste une cohérence qui permet d'y voir um ordre juridique (par opposition à um chaos), et c'est assez pour y reconnaître um système, au sens où les juristes, spécialement internationalistes, emploient habituellement ce mot. Même s'il presente dês caractères qui le différencient de son correspondant interne, il satisfait deux conditions dont la réunion este nécessaire pour qualifier um ensemble d'éléments d'ordre, ou de système, juridique: l'ensemble des normes internationales est 'ordonné', comme le sont les rapports entre les normes internationales et les conduites qu'elles on pour objet de régir" (pp. 87-88).

${ }^{32}$ VERDROSS, Alfred. Op. cit., p. 63.

${ }^{33}$ VERDROSS, Alfred. Op. cit., p. 64

${ }^{34}$ KELSEN, Hans. Teoria Pura do Direito. São Paulo: Martins Fontes, 1999, pp. 355-356. 
jurista, o Direito internacional impõe deveres e confere direitos aos Estados, na medida em que os obriga a adotar uma determinada conduta, ao ligar à conduta oposta as sanções da guerra e das represálias, e em que o direito reflexo dos Estados é revestido do poder que estes têm de recorrer à guerra e às represálias contra o Estado que viola o seu dever ${ }^{35}$.

Entretanto, Kelsen salienta que o Direito internacional não institui estes direitos deveres diretamente - como faz a ordem jurídica interna - mas indiretamente, através da ordem jurídica interna. De fato, o Direito internacional apenas determina o que deve ser feito ou omitido, mas deixa para o Direito interno a determinação do indivíduo que tem de realizar a atuação ou omissão previstas ${ }^{36}$.

$\mathrm{Na}$ ótica kelseniana, o Direito internacional teria como norma fundamental a que instituísse como fato gerador de Direito o costume constituído pela conduta recíproca dos Estados. A partir desta norma, dar-se-ia então a construção escalonada do Direito internacional com o costume, que atribui direitos e impõe deveres a todos os Estados, o Direito internacional pactício, que regula a conduta recíproca dos sujeitos da comunidade internacional através de tratados, e ainda, as normas criadas pelos tribunais internacionais $\mathrm{e}$ por outros órgãos pacticiamente constituídos ${ }^{37}$.

Diante de todos estas considerações, parece, pois, inegável o caráter jurídico do Direito internacional. Da mesma forma, é irrefutável que ao Direito interno cabe a sua efetiva concretização. E isto nos remete à segunda etapa de nosso estudo.

\section{A RELAÇÃO DO DIREI- TO INTERNACIONAL COM O DIREITO IN- TERNO}

\section{a) As Teorias que Tratam da Relação}

Há quem, como Heber Arbuet Vignali Jean Michel Arrighi, entenda que a discussão em torno das teorias que buscam explicar a relação entre o Direito internacional e o Direito

${ }^{35}$ KELSEN, Hans. Op. cit., pp. 358 e 360. Ainda que veja no Direito internacional, como ordem coerciva, o mesmo caráter do Direito estatal, Kelsen deste o distingue por ver no Direito internacional uma certa semelhança com o Direito da sociedade primitiva, em função de não instituir ele órgãos que funcionem segundo o princípio da divisão do trabalho para a criação e aplicação das suas normas. Para Kelsen, o Direito internacional estaria ainda em um estágio de grande descentralização, carente de uma instância objetiva que decida o litígio através de um processo juridicamente regulado $e$ assitindo a vigência da técnica da autodefesa (pp. 358-359).

${ }^{36}$ KELSEN, Hans. Op. cit., p. 361. Isto não impede, contudo, que em alguns casos o Direito internacional imponha deveres diretamente aos indivíduos, os quais são constituídos através de sanções específicas do imponha deveres diretamente aos indivíduos, os quais são constituídos através de sanções específicas do
Direito estatal, quais sejam, penas e execuçôes. Tal é o caso do delito internacional de pirataria e dos crimes de guerra (p. 363).

${ }^{37}$ KELSEN, Hans. Op. cit.., pp. 359-60.

Revista da Faculdade de Direito da UFRGS, v. 21, Março/2002

interno não mais interessaria ${ }^{38}$. Não nos parece, no entanto, que a sua importância deva ser subestimada. Afinal, o combate travado pelos ilustres defensores das suas duas principais correntes manteve por muito tempo o Direito internacional sob a luz dos holofotes, o que muito contribuiu para o seu desenvolvimento e para o desenvolvimento da ciência do Direito como um todo.

Isto apenas já justifica, portanto, o exame das teorias que se ocupam da relação entre o Direito internacional e o Direito interno. Somese a isto o fato de que a real eficácia do Direito internacional depende de como esta relação se estabelece e se torna impossível negar que a adequada compreensão do tema que é objeto de nosso estudo exige a realização desta análise.

São duas as principais teorias que tratam da relação entre o Direito internacional e o Direito interno: a Teoria Dualista, para a qual Direito internacional e Direito interno regulam relações distintas e possuem sujeitos, fontes e objetos essenciaimente diferentes; e a Teoria Monista, que defende a existência de um único conjunto de normas jurídicas, que compreenderia o Direito internacional e os inúmeros $\mathrm{Di}$ reitos internos, estabelecendo-se entre eles relações de subordinação ${ }^{39}$. E a forma com que

tal relação se estabelece divide ainda o monismo em duas outras correntes: o Monismo com primado do Direito internacional e o Monismo com primado do Direito interno.

A concepção dualista (Fig. 1) afirma que o Direito internacional e o Direito interno são dois ordenamentos jurídicos completamente separados, inexistindo entre eles uma relação sistemática e sendo, por conseguinte, impossível a ocorrência de um conflito entre as normas de cada um dos mesmos. Ademais, para que uma norma internacional viesse a produzir efeitos na ordem interna teria de ser assimilada pelo Direito interno, ou seja, teria de transformar-se numa norma de Direito interno. Esta teoria foi elaborada por Triepel e encontrou grande receptividade na doutrina italiana, onde foi defendida principalmente por Anzilotti ${ }^{40}$.

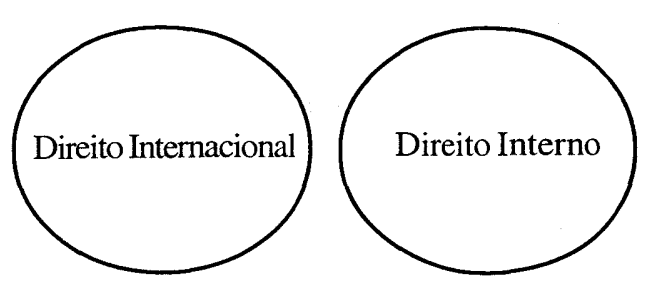

Fig. 1. Teoria Dualista

${ }^{38}$ VIGNALI, Heber Arbuet \& ARRIGHI, Jean Michel. "Os Vínculos éntre o Direito Internacional Público e os Sistemas Internos" in Revista de Informação Legislativa, $\mathrm{n}^{\circ} 115$, Julho-Setembro 1992, p. 414. Isto porque, segundo estes autores, "o desenvolvimento de ambas as teses demonstrou que se pode ser monista ou dualista e sustentar a primazia da ordem interna ou da ordem internacional, e porque geralmente tanto monistas como dualistas, além das correntes coordenadoras e normalmente a prática dos Estados, aceitam pacificamente a
primazia do Direito Internacional Público" (p. 414-415).

${ }^{39}$ ARRIGHI, Jean Michel. "La Solución de Controversias entre Normas Internacionales y Normas Nacionales (con especial referencia al MERCOSUR)" in Boletim da Sociedade Brasileira de Direito Nacional, $\mathrm{n}^{\circ} 45$ e 46 , Janeiro-Junho 1994, p. 43. Este autor diferencia ainda os objetivos das teorias dizendo que para os monistas a questão era determinar a relação hierárquica entre as normas internas e as internacionais; para os dualistas era determinar como se vinculavam as duas ordens, tidas por distintas.

${ }^{40}$ ANZILOTTI, Dionísio. Cours de Droit International. Paris:Recueil Sirey, 1929, v. I. Diz este autor: "Emanant de normes fondamentales autonomes, le droit international et le droit interne sont, par suite, des ordres séparés" (p. 51) 
As principais criticas feitas por Verdross a esta orientação são no sentido de que um dualismo conseqüente conduziria à própria negação do Direito internacional. Afinal, caso os órgãos estatais devessem e pudessem aplicar apenas o seu próprio ordenamento jurídico, nem mesmo os órgãos supremos poderiam aplicar o Direito internacional. Da mesma forma, para Verdross, esta teoria se autorefutaria na medida em que, mesmo admitindo a impugnação do Direito interno contrário ao Direito internacional segundo um procedimento jurídico-internacional, ela nega, não obstante, a subordinação do Direito interno ao Direito internacional ${ }^{41}$.

Franceschini acrescenta que a concepção dualista "não esclarece como as partes de um tratado podem pedir reparação pela violação do Direito Internacional, sendo certo, segundo os críticos, que a eventual reparação da ofensa restituiria ao Direito Internacional seu caráter supremo" 42 . E Jean Michel Arrighi

encerra a questão apontando que "la práctica interna de los Estados demuestra que, muchas vezes, la norma internacional es directamente incorporada al orden interno sin necesidad de ninguna transformación" e que "el dualismo tampoco logra explicar la existencia de fuentes de derecho internacional que, como la costumbre o las relaciones de algunas organizaciones internacionales, pueden obligar a los Estados, las hayan aprobado o no"43.

Por outro lado, de acordo com a Teoria Monista, o Direito internacional é concebido ou como uma ordem jurídica delegada pela estatal e, assim, nela incorporada, ou como uma ordem jurídica total que delega nas ordens estatais, as quais seriam abrangidas pela ordem internacional, superior a elas ${ }^{44}$. Como já referido, temos, assim, respectivamente, dentro da Teoria Monista, duas vertentes: o monismo com primado do Direito interno e o monismo com primado do Direito internacional ${ }^{45}$.

${ }^{41}$ VERDROSS, Alfred. Op. cit., pp. 66 (nota ${ }^{\circ} 5$ ) e 68. No mesmo sentido, Celso D. de Albuquerque Mello (op cit., p. 45), que faz também uma interessante colocação: "se a validade dos tratados internacionais repousass ñão na ordem constitucional pstar um processo revolucionário deveria acarretar a Wenzel, toda modificatratados, concluídos na vieência do regime anterior. Entretanto, isso não ocorre, porque em nome de continudade e permanência do Estado ele é ainda obrigado a cumprir os tratados conclú́dos no regime jurídico anterion (loc. cit.)

${ }^{42}$ FRANCESCHINI, José Inácio G.. Op. cit., p. 29.

${ }^{43}$ ARRIGHI, Jean Michel. Op. cit., p. 44.

KELSEN, Hans. Op. cit., pp. 369-370. Riccardo Monaco, adepto do dualismo, sintetiza as críticas feitas ao monismo, afirmando que: "La conception moniste ressemble plutôt à une hypothèse qu'à une véritable théorie: si séduisante qu elle puisse apparaitre et apte a faciliter la solution de problèmes delicats de la théor du droit international, elle a le tort de ne pas correspondre à l'evolution historique du droit international, à ses applications pratiques" ("Cours Général sur des Príncipes de Droit International Public" in Recueil des ${ }_{45}$ Cours, Tome 125. Holanda: A.W. Sijthoff, 1970, p. 251)

KELSEN, Hans. Op. cit, pp. 369-370. Kelsen distingue estas correntes nos seguintes termos: "A diferença entre as duas validade do Direito intemacional ño ao seu conteúdo. Segundo a primeir gue tem o seu ponto de partida ma validate uma ordem jurídica estadual, o fundamento de validade do Direito internacional é a norma fundamental pressuposta por força da qual a fixação da primeira Constituição histórica do Estado, cujo ordenamento forma o ponto de partida construção, é um fato gerador de Direito. Segundo a outra, que não toma o seu ponto de partida numa ordem jurídica estadual mas no Direito intemacional, o seu fundamento de validade é a norma fundamental pressuposta por virtude da qual o costume dos Estados é um fato gerador de Direito" (p. 378). Para Kelsen, o primado do Direito internacional desempenha um papel importante na ideologia política do pacifismo e o primado do Direito interno na do imperialismo (p. 382). Jean Michel Arrighi menciona um terceiro caminho, aquele segundo o qual "tanto el orden jurídico internacional como los ordenes juridicos intermos están incluidos em um tercer orden comün a ambos, se afilian a la existencia de um derecho natural cuyos principios informan a todos los órdenes jurídicos positivos, lo que no resuelve el posible conflicto entre
normas de distintos ordenes" (op. cit., loc. cit.). Kelsen também aventa a possibilidade de uma terceira soluçấo (p. 369).
A ótica monista com primado do Direito interno (Fig. 2) teve por defensores, entre outros, Wenzel, Decencière-Ferrandière e Jellinek, inspirados pelas idéias de Hegel, cuja posição, já referida, se fundamentava na supremacia do direito estatal ${ }^{46}$. Para esta corrente, o Direito internacional é concebido como uma ordem jurídica delegada pela estatal e, por conseguinte, nela incorporada. Assim, ao entender que o Direito internacional apenas vigora em relação a um Estado quando este o reconhece como vinculante, esta teoria termina por reduzir o Direito internacional a uma simples parte do Direito interno. Como bem aponta Kelsen, de acordo com esta visão, o Direito internacional adquire contornos de um "Direito estatal externo" 47 . No entendimento de Franceschini, daí viria a principal critica à adoção desta teoria, pois ela "implicaria a negação da existência do direito internacional como direito autônomo e independente" 48

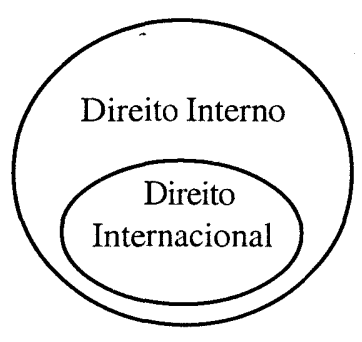

Fig. 2. Teoria Monista com primado do Direito Interno

${ }^{46}$ FRANCESCHINI, José Inácio G.. Op. cit., p. 28

${ }^{47}$ KELSEN, Hans. Op. cit., p. 373.

${ }^{48}$ FRANCESCHINI, José Inácio G.. Op. cit., loc. cit.. No mesmo sentido, Jean Michel Arrighi, op. cit., loc. cit.

${ }^{49}$ VERDROSS, Alfred. Op. cit.., pp. 65-66. O mesmo autor, contudo, bem lembra que os órgãos internacionais chamados a se pronunciar sobre leis internas frente ao Direito internacional não têm competência para derrogá-las. Eles apenas podem comprovar sua oposição ao Direito internacional e sugerir ao Estado culpável que promova a sua derrogação ou a sua não aplicação (p. 67). Emile Giraud, adepto do monismo com primado do direito internacional, diz que: "Le principe de la supériorité du droit international sur le droit interne est fondamental. Affirmer cette supériorité ce n'est pás proclamer um ideal, c'est simplement constater ce qui est" ("Le Droit International Public et la Politique" in Recueil des Cours, Tome 110 Holanda: A.W. Sijthoff, 1966, p. 601). 


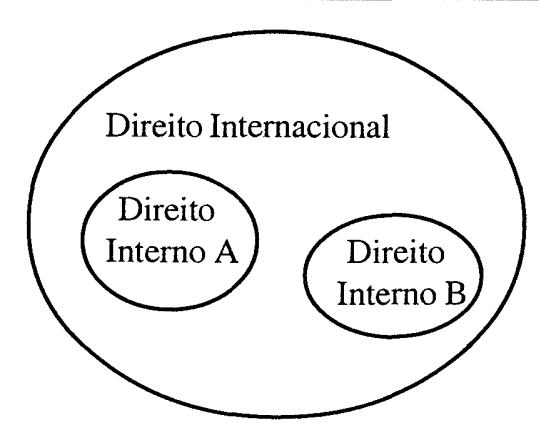

Fig. 3. Teoria Monista com primado do Direito Internacional

Enfim, parece-nos que existe entre o Direito internacional e o Direito interno uma determinada conexão sistemática que não pode ser negada ou desconsiderada. Não obstante, Heber Arbuet Vignali e Jean Michel Arrighi bem apontam que o Direito internacional positivo não adere nem à corrente dualista, nem à monista $^{50}$.

Pastor Ridruejo, citado pelos mesmo autores, afirma que a importância da relação entre o Direito internacional e o Direito interno advém do fato de que a real eficácia do Direito internacional "depende, em grande parte, da fidelidade com que os Direitos nacionais $s$ ajustem às normas internacionais e lhes dêem eficácia... É essencial, nesse sentido, que o Direito nacional facilite o cumprimento do Direito internacional e, mais ainda, em caso de conflito, o Direito do Estado não seja obstáculo à observância das normas internacionais" $" 51$. E é justamente a temática das soluções que são dadas pelo Direito internacional e pelos ordenamentos internos para os conflitos que se estabelecem entre as suas normas que será 0 objeto da última etapa deste estudo.

\section{b) Os Conflitos entre o Direito Internacional e o Direito Interno}

O Direito internacional positivo, apesar de não assumir posição no que concerne à querela monismo-dualismo, consagra a prevalência do Direito internacional sobre o Direito interno em caso de conflitos. Faz isto através do artigo 13 da Resolução 375 (IV) da Assembléia Geral das Nações Unidas e do artigo 27 da Convenção de Viena, de 1969, sobre Direito dos Tratados ${ }^{52}$. A jurisprudência dos tribunais internacionais, como não poderia deixar de fazer, reproduz este entendimento ${ }^{53}$.

O tema se torna mais complexo, no

${ }^{50}$ VIGNALI, Heber Arbuet \& ARRIGHI, Jean Michel. Op. cit., p. 415

${ }^{51}$ VIGNALI, Heber Arbuet \& ARRIGHI, Jean Michel. Op. cit., p. 414

${ }^{52}$ Cf. ARRIGHI, Jean Michel. Op. cit., p. 45. Dizem tais normas, respectivamente, que: “Art. 13. Todo Estado tem o dever de cumprir de boa-fé as obrigações emanadas dos tratados e de outras fontes de Direito internacional, e não pode invocar disposições de sua própria Constituição ou de suas leis como desculpa para deixar de cumprir este dever"; e "Art. 27. Uma parte não poderá invocar as disposições de seu Direito interno como justificação para o descumprimento de um tratado. Esta norma se entenderá sem prejuízo do disposto no artigo 46", o qual dá a única exceção: "Art. 46. (...) a não ser que esta violação seja manifesta e afete uma norma de importância fundamental de seu Direito interno" (loc., cit.). Arrighi acrescenta ainda que a Convenção de Havana sobre Tratados de 1928, em seus artigos 10,11 e 12, já estabelecia a primazia do Direito internacional e que tanto os tribunais arbitrais como a Corte Internacional, a Corte de Direitos Humanos e a Corte das Comunidades Européias também sempre consagraram o princípio da superioridade do Direito internacional (pp. 45-46). Verdross também manifesta esta impressão (op. cit., p. 68). É interessante observar que a Convenção de Viena adotou uma postura eclética, prevalecendo em princípio a norma internacional e como

${ }^{53}$ Assim apontam Jean Michel Arrighi (op. cit., p. 46), Jean Michel Arrighi e Heber Arbuet Vignali (op. cit., p. 419) e Luiz Flávio Gomes ("A Questão da Obrigatoriedade dos Tratados e Convenções no Brasil (Particular Enfoque da Convenção Americana sobre Direitos Humanos)" in Revista dos Tribunais, $\mathbf{n}^{\circ} 710$, Dezembro 1994, p. 24).

Revista da Faculdade de Direito da UFRGS, v. 21, Março/2002 entanto, quando enfocado a partir da perspectiva dos diversos ordenamentos internos. Antonio Cassese, citado por George Rodrigo Bandeira Galindo, divide as Constituições, no que tange ao tratamento que dispensam aos tratados internacionais, em quatro grupos distintos: 1) Constituições que ignoram a questão da implementação dos tratados;2) Constituições que estabelecem que as obrigações convencionais devem ser obedecidas por todos os cidadãos e funcionários dentro do Estado, mas que não garantem aos tratados superioridade hierárquica em relação às leis ordinárias; 3) Constituições que prevêem a supralegalidade dos tratados; $\mathrm{e}$ 4) Constituições que permitem que tratados modifiquem ou revisem disposições constitucionais $^{54}$

Nesse contexto, é interessante examina como alguns ordenamentos internos enfrentam a questão. Apesar de sabermos de antemão que encontraremos mais de uma solução, o exame comparativo servirá para nos apontar, dentre os possíveis, qual o caminho mais comumente adotado hoje ao redor do mundo.

Na Holanda, tanto a Constituição de 1972, revisada em 1983, como a jurisprudência reconhecem a supremacia dos tratados internacionais sobre as leis internas. Em seu artigo 94, a Constituição holandesa estabelece:

"Não serão aplicáveis as normas jurídicas vigentes no Reino quando sua aplicação seja incompatível com as disposições de um tratado ou com as resoluções das instituições internacionais que obriguem os particulares" $"$.

Segundo Vignali e Arrighi, a supremacia do Direito internacional também teria sido reconhecida na Bélgica, a partir de um acórdão da Corte de Apelação de Bruxelas, de 1971 (caso "Fromagerie Franco-Suisse Le Ski") ${ }^{56}$. Na Alemanha, a própria Constituição, em seu artigo 25, já acolhe esta orientação, ao estabelecer que: "As normas gerais do Direito internacional público são parte integrante do Direito federal, tem primazia sobre as leis e são fonte direta de direitos e obrigações para os habitantes do território federal" 57 .

Após longa discussão, na Itália, a primazia do Direito internacional em relação ao Direito interno teria sido admitida pelo Tribunal Constitucional, em 1984 (caso "Granifal") Entretanto, apesar deste reconhecimento, deve ser ressaltado que em função da falta de previsão constitucional expressa, a jurisprudência majoritária permanece atrelada à doutrina dualista. Com isto, os tratados têm de ser transformados em lei interna para gerar direitos e obrigações, e podem, assim, ser modificados por uma lei posterior ${ }^{59}$ ${ }^{54}$ GALINDO, George Rodrigo Bandeira. "Reforma Constitucional e o Problema da Superioridade Hierárquica dos
Tratados Frente às Leis Internas" in Cadernos de Direito Constitucional e Ciência Política, $\mathbf{n}^{\circ} 27$, Abril-Junho 1999, p. 144. Segundo Cassese, os dois primeiros grupos seriam dominados por aspiraçôes nacionalistas, enquanto os dois últimos seriam mais "internacionalmente orientados".

${ }^{5 s}$ Cf. VIGNALI, Heber Arbuet \& ARRIGHI, Jean Michel, op. cit., p. 417; e ARRIGHI, Jean Michel, op. cit., p. 48. Luiz Flávio Gomes salienta, entretanto, que as normas internacionais não chegam ao mesmo patamar das regras constitucionais, ocupando apenas uma posição de destaque no ordenamento infraconstitucional (op. cit., loc. cit.).

${ }^{56}$ Cf. VIGNALI, Heber Arbuet \& ARRIGHI, Jean Michel, op. cit., p. 418.

${ }^{57}$ ARRIGHI, Jean Michel, op. cit., p. 48.

${ }^{58}$ Cf. VIGNALI, Heber Arbuet \& ARRIGHI, Jean Michel, op. cit., loc. cit.

${ }^{59}$ ARRIGHI, Jean Michel, op. cit., loc. cit. 
Na França, a Constituição de 1958, em seu artigo 55, dispõe que: "Os tratados ou acordos regularmente ratificados ou aprovados têm, desde sua publicação, uma autoridade superior às leis, sob condição, para cada acordo ou tratado, de sua aplicação pela outra parte". Contudo, em que pese este claro comando constitucional, a jurisprudência está dividida. Enquanto o Tribunal de Cassação sustenta a primazia do tratado, o Conselho de Estado mantém uma posição contrária à primazia do Direito internacional sobre lei posterior ${ }^{60}$.

A Constituição de Portugal trata do tema em foco no item 1 de seu artigo $8^{\circ}$, que dispõe: "As normas e os princípios de Direito internacional geral ou comum fazem parte integrante do Direito português". E, ainda, no item 2 do seu artigo 277: “A inconstitucionalidade orgânica ou formal dos tratados internacionais regularmente ratificados não impede a aplicação de suas normas na ordem jurídica portuguesa, desde que tais normas sejam aplicadas na ordem jurídica da outra parte, salvo se tal inconstitucionalidade resultar de violação de uma disposição fundamental".

Na Grécia, o artigo 28 da Constituição de 1975, em seu item 1, determina que: “As regras geralmente reconhecidas do Direito internacional e as convenções internacionais após serem ratificadas e em vigor de acordo com seus respectivos termos, constituem parte integrante do Direito grego e se sobrepõe a qualquer disposição legal em contrário. A aplicação das regras do Direito internacional e convenções

internacionais no caso de estrangeiros deve ser sempre efetuada em condições de reciprocidade". Entretanto, apesar desta clara determinação, a jurisprudência tem vacilado, atribuindo muitas vezes primazia à norma interna ${ }^{61}$.

Nos termos do parágrafo $1^{\circ}$ do artigo 96 da Constituição espanhola de 1978: "O tratados internacionais validamente celebrados, uma vez publicados oficialmente na Espanha, farão parte do ordenamento interno. Suas disposições só poderão ser derrogadas, modificadas ou suspensas na forma prevista nos próprios tratados ou de acordo com as normas gerais do Direito internacional". Também neste caso houve vacilação por parte da jurisprudência para resolver a questão da hierarquia entre as normas do Direito internacional e do Direito interno. De fato, ao mesmo tempo em que o Tribunal Supremo proclamou, em decisão de 1985, a supremacia dos tratados, atribuindo-lhes "um valor superlegal e quase constitucional", há outros julgados que dão prevalência às normas internas $^{62}$

$\mathrm{Na}$ Inglaterra, quanto à hierarquia, a tendência da jurisprudência era no sentido de que o tratado faz parte do Direito interno ("international law is part of the law of the land") e pode ser derrogado por um ato parlamentar posterior. Este entendimento, contudo, tenderia a se alterar em virtude do ingresso dos britânicos na Comunidade Econômica Européia, passando-se a atribuir primazia ao Direito internacional ${ }^{63}$.

${ }^{60}$ Cf. VIGNALI, Heber Arbuet \& ARRIGHI, Jean Michel, op. cit., loc. cit., e ARRIGHI, Jean Michel, op. cit., p. 47. ${ }^{61}$ Cf. ARRIGHI, Jean Michel. Op. cit., p. 48.

${ }^{62}$ Cf. ARRIGHI, Jean Michel. Op. cit., p. 49.

${ }^{63}$ Cf. ARRIGHI, Jean Michel. Op. cit., p. 47. O autor aponta que, na Inglateræa, a aprovação e ratificação de tratados são prerrogativas da Coroa, sem que haja participação do parlamento. Todggvia, para evitar que dest forma a Coroa possa legislar sem o acordo do parlamento, na hipótese de tratados que acarretem encargos para os fundos públicos ou que afetem direitos privados, os mesmos só podem ser aplicados pelo juiz nacional mediante prévia autorização parlamentar. E a delimitação dos tratados que requerem aprovação parlamentar é realizada pelo próprio juiz, caso a caso (loc. cit.).

Revista da Faculdade de Direito da UFRGS, v. 21, Março/2002
Nos Estados Unidos, o item 2 do artigo VI da Constituição de 1787 determina: "Esta Constituição e as leis dos Estados Unidos que sejam ditadas de acordo com ela, e todos os tratados celebrados ou que se celebrem sob a autoridade dos Estados Unidos serão a Lei suprema da Nação; e os juízes, em cada Estado, estarão sujeitos a elas ainda que a Constituição ou as leis do Estado disponham o contrário". Em caso de conflito entre uma norma de Direito internacional e uma lei nacional, a jurisprudência tem aplicado a chamada doutrina "last in time", segundo a qual ambas têm a mesma a hierarquia, prevalecendo a que for posterior. De qualquer forma, a jurisprudência também tem afirmado que a Constituição é hierarquicamente superior ao tratado ${ }^{64}$.

A Constituição argentina, claramente inspirada na norte-americana, dispõe em seu artigo 31: "Esta Constituição, as leis da Nação que em sua conseqüência dite o Congresso e os tratados com as potências estrangeiras, são a lei suprema da Nação; e as autoridades de cada província estão obrigadas a conformar-se a ela, não obstante qualquer disposição em contrário que contenham as leis ou constituições provinciais, salvo para a Província de Buenos Aires, os tratados ratificados depois do Pacto de 11 de novembro de 1859". O artigo 75 da Constituição Argentina também dispõe sobre a matéria ao delimitar as atribuições do

\section{Congresso: "Compete ao Congresso: (...) 22.} Aprovar ou rejeitar tratados celebrados com outras nações e organizações internacionais e as concordatas ${ }^{65}$ com a Santa Sé. Os tratados e concordatas têm hierarquia superior às leis" ${ }^{\prime 66}$. via a supremacia do tratado sobre a lei, ao dispor em seu artigo 101 que: "Os tratados internacionais celebrados pelo Peru com outros Estados, fazem parte do Direito nacional. Em caso de conflito entre o tratado e a lei, prevalecerá o primeiro". A doutrina e a jurisprudência peruanas, entretanto, asseguravam primazia às normas constitucionais, quando estas entrassem em conflito com normas internacionais ${ }^{67}$. A nova Constituição de 1993, em seu artigo 55, refere apenas que: "Os tratados celebrados pelo Estadoe em vigor fazem parte do Direito nacional”.

No Chile, não há disposição constitucional expressa a respeito da questão. A jurisprudência, em se tratando de conflito de norma interna com costume internacional, geralmente dá prevalência ao Direito interno. Já quando o conflito é com um tratado, ela tem entendido que este possui a mesma hierarquia que a lei interna, prevalecendo, em qualquer caso, as normas constitucionais ${ }^{68}$.

Também a Constituição do Uruguai se omite sobre o problema, apresentando apenas disposições sobre os órgãos competentes para
A constituição peruana de 1979 pre-

${ }^{64}$ Cf. ARRIGHI, Jean Michel. Op. cit., p. 49.

${ }_{65}$ "Concordata" aqui tem o significado de "convenção entre o Estado e a Igreja acerca de assuntos religiosos de uma nação" (Cf. FERREIRA, Aurélio Buarque de Holanda. Novo Dicionário da Lingua Portuguesa. Rio de Janeiro: Nova Fronteira, 1986, p. 447).

${ }^{66}$ Este mesmo item confere expressamente à Declaração Americana dos Direitos e Deveres do Homem, à Declaração Universal dos Direitos Humanos e à Convenção Americana sobre Direitos Humanos, entre outras, hierarquia constitucional, de forma complementar aos direitos e garantias reconhecidos pela Constituição, sem poder, no entanto, derrogar qualquer artigo da Primeira Parte desta. É interessante observar que, conforme Jean Michel Arrighi, em decisão de 1992, ou seja, antes mesmo da Reforma constitucional de 1994, a Corte Suprema de Justiça da Nação já havia sustentado a primazia da Convenção Americana sobre Direitos Humanos sobre as leis internas, assim como a sua aplicação direta (op. cit., pp. 50-51).

${ }^{67}$ Cf. ARRIGHI, Jean Michel. Op. cit., p. 50

${ }^{68}$ ARRIGHI, Jean Michel. Op. cit., loc. cit.

Revista da Faculdade de Direito da UFRGS, v. 21, Março/2002 
a aprovação e ratificação de tratados. Segundo Jean Michel Arrighi, no que concerne a conflitos entre tratados e leis, salvo algumas decisões, os tribunais em geral atribuem a ambas as normas a mesma hierarquia e em caso algum hierarquia superior ou igual à Constituição ${ }^{69}$.

Finalmente, cumpre enfocar mais atentamente o tratamento que é dado a matéria pelo nosso ordenamento jurídico. Da mesma forma que no Uruguai, a Constituição Federal brasileira de 1988 não se pronunciou sobre a questão da hierarquia existente entre normas internacionais e internas, veiculando tãosomente disposições sobre os procedimentos de aprovação e ratificação de tratados internacionais (artigos 49, I, e 84, VIII).

Devemos começar, portanto, pelo procedimento que deve ser seguido para que os tratados internacionais passem a vigorar internamente no Brasil. Devidamente firmado, o tratado deve ser aprovado pelo Congresso Nacional, por maioria absoluta de votos, mediante a edição de decreto legislativo promulgado pelo Presidente do Senado Federal. Assim aprovado, o tratado pode então ser ratificado pelo Presidente da República em nome da República Federativa do Brasil. Também ao Presidente da República cabe, através de decreto, promulgar o tratado, incorporando-o ao ordenamento jurídico interno e passando o mesmo a ser aplicado de forma geral obrigatória, vinculando poderes públicos particulares $^{70}$.

${ }^{69}$ ARRIGHI, Jean Michel. Op. cit., pp. 52 e 54

${ }^{70}$ Cf. MORAES, Alexandre de. Direito Constitucional. São Paulo: Atlas, 2001, p. 550

${ }^{11}$ GOMES, Luiz Flávio. Op. cit., p. 22. O autor lembra a lição de João Grandino Rodas: "É corolário da teoria dualista a necessidade de, através de alguma formalidade, transportar o conteúdo normativo dos tratados para o direito interno, para que estes, embora já existentes no plano internacional, possam ter validade e executoridade no território nacional. Consoante o monismo, não será necessária a realização de qualquer ato pertinente ao direito interno após a ratificaçāo".

${ }^{72}$ GOMES, Luiz Flávio. Op. cit., p. 23. Neste mesmo sentido é a manifestação de Luiz Olavo Baptista ("Inserção dos Tratados no Direito Brasileiro" in Revista de Informação Legislativa, ${ }^{\circ}$ 132, Outubro-Dezembro 1996, p. 73). a norma internacional conflita com a Constituição. Estas são as três hipóteses possíveis na perspectiva do "sistema diferenciador" $" 73$.

Para aqueles que seguem esta corrente, no primeiro caso, a norma internacional possuiria valor constitucional e revogaria todas as disposições internas que lhe fossem contrárias. Na segunda hipótese, em que se tem um direito não previsto, mas de acordo com nosso ordenamento, aplicar-se-ia o artigo $5^{\circ}$ parágrafo $2^{\circ}$, da Constituição Federal, adquirindo a norma internacional força de lei ordinária e resolvendo-se eventuais conflitos pelo princípio lex posterior derogat priori. Finalmente, no terceiro caso, prevaleceria a Constituição ${ }^{74}$

A maior parte da doutrina, entretanto, não costuma fazer esta distinção. Na verdade,

${ }^{73}$ GOMES, Luiz Flávio. Op. cit., p. 25.

${ }^{74}$ GOMES, Luiz Flávio. Op. cit., loc. cit.. Nesta linha, Luiz Olavo Baptista afirma que: "No Brasil, desde a Constituição de 1988, temos algumas regras de direito internacional que, introduzidas no direito brasileiro, não mais podem ser revogadas, pois estão sob o império da chamada cláusula pétrea" (op. cit., p. 74).

${ }^{75}$ GOMES, Luiz Flávio. Op. cit., p. 26. Jean Michel Arrighi cita os mesmos precedentes (op. cit., p. 52). Em outro artigo, entretanto, Heber Arbuet Vignale e Jean Michel Arrighi, afirmam que desde 1941, decisões do STF reconheceriam a aplicabilidade dos tratados na ordem interna, mesmo com o advento de lei posterior contrária (op. cit., p. 418). George Rodrigo Bandeira Galindo, no entanto, observa que há autores que entendem que a jurisprudência não era pacífica neste sentido (op. cit., p. 147). ${ }^{76}$ Diz o artigo 98 do CTN: "Os tratados e as convenções internacionais revogam ou modificam a legislação política que permeia o problema da superioridade hierárquica dos tratados perante as leis internas. A jurisprudência do STF sobre os conflitos entre tratados internacionais em matéria tributária e o Direito interno é examinada com mais detalhes por José Fernando Cedeño de Barros ("Monismo e Dualismo - Tratados Internacionais nada com mais detalhes por José Fernando Cedeño de Barros ( Mo Tribunal Federal - Interpretação do Art. 98 do CTN" in Cadernos de Direito Tributário, $n^{\circ} 27$, pp. 79-94). "Cabe reproduzir, pela sua importância, o seguinte trecho do voto do Ministro Cunha Peixoto: "se a lei uniforme
transformou-se em direito positivo brasileiro, evidente que pode ser modificada ou revogada, como qualquer transformou-se em direito positivo brasileiro, evidente que pode ser modificada ou revogada, como qualquer
outro diploma legal. Do contrário transformar-se-ia qualquer lei que procedesse de algum tratado em super-lei, outro diploma legal. Do contrário transformar-se-ia qualquer lei que procedesse de algum tratado em super-lei,
em situação superior à própria Constituição brasileira... Portanto, ou o tratado se transforma, pela simples ratificação, em lei ordinária, no Brasil, ou, então, não poderá ser revogada ou modificada pelo congresso, como qualquer outra lei...". Igualmente pertinente a lição de Lélio Candiota de Campos, citado pelo Ministro Cordeiro Guerra em seu voto: "Parece, outrossim, que o direito entrado pela via da recepção do tratado está no mesmo plano de igualdade que o internamente elaborado, não sendo superior a este. Nossa Constituição não contém norma expressa de predominância do Direito internacional, como a francesa... No próprio Direito americano, onde se reconhece ao tratado o caráter de 'supreme law of the land', contudo, não se veda a posterior elaboração legislativa a ele contrária...". 
acolheu a tese de que ao ser incorporada ao ordenamento nacional, a norma internacional adquire força de lei ordinária.

Cabe salientar também que, diversamente da tese supra referida de Luiz Flávio Gomes, esta mesma jurisprudência atribui aos tratados nível hierárquico sempre inferior ao da Constituição, sujeitando-os, pois, inclusive ao controle de constitucionalidade. E a doutrina também abraça esta orientação ${ }^{78}$.

De qualquer forma, o certo é que diante desta orientação, os conflitos que porventura ocorrerem entre tratados internacionais e leis internas serão resolvidos pelo princípio lex posterior derogat priori. Isto significa dizer que tratado posterior revoga lei anterior e lei posterior revoga tratado anterior ${ }^{79}$.

A este respeito, no entanto, deve-se observar que já em seu voto no célebre Recurso Extraordinário ${ }^{\circ} 80.004$, o Ministro Leitão de Abreu fazia um necessário registro. Dizia ele: “ lei posterior, em tal caso, não revoga, em sentido técnico, o tratado, senão que lhe afasta aplicação. A diferença está em que, se a lei

revogasse o tratado, este não voltaria a aplicarse, na parte revogada, pela revogação pura e simples da lei dita revogatória". Ou seja, a lei posterior contrária não revogaria, propriamente, o tratado, mas, sim, o tornaria inaplicável pelos tribunais nacionais ${ }^{80}$

Por outro lado, cabe apontar que em sendo negada aplicabilidade ao tratado no âmbito interno, o Estado poderá ser responsabilizado na esfera internacional pelo seu descumprimento. Afinal, internacionalmente subsistirá sua obrigação perante os demais signatários do tratado.

Diante de todos os exemplos acima referidos, constatamos a existência de basicamente quatro soluções para a questão dos conflitos que se estabelecem entre os tratados internacionais e os ordenamentos internos dos países: 1) a primazia das leis internas; 2 ) a primazia dos tratados; 3 ) a equivalência hierárquica entre tratados e leis; e, finalmente, 4) a atribuição de status constitucional ou de lei ordinária aos tratados conforme o caso concreto ${ }^{81}$.

De qualquer forma, parece claro que a

${ }^{78}$ Neste sentido, George Rodrigo Bandeira Galindo (op. cit., p. 153). Luiz Olavo Baptista ainda defende a tese de que "o tratado, ainda que verse sobre matéria típica de lei complementar, não passará do nível da lei ordinária ..." "Para que faça efeito - ainda que promulgado - faz-se necessária a edição de lei complementar que incorpore seus preceitos no direito brasileiro", reconhecendo, contudo, que não há precedente judicial que a sustente (op. cit., p. 75).

${ }^{79}$ Nesse sentido, a lição de Jacob Dollinger: "A posição do STF através dos tempos é de coerência e resume-se a dar o mesmo tratamento a lei e ao tratado, sempre prevalecendo o diploma posterior, excepcionados os tratados fiscais e de extradiç̃o, que por sua natureza contratual exigem denúncia formal para deixarem de ser cumpridos" (apud Luiz Olavo Baptista op. cit, p. 78). George Rodrigo Bandeira Galindo também aponta ser cumpridos" (apud Luiz Olavo

${ }^{80}$ Ainda no que diz respeito ao rigor técnico no tratamento da matéria, no julgamento da Apelação Cível ${ }^{\circ}$ 41.938 pelo Tribunal de Justiça do Rio Grande do Sul, o então Desembargador Athos Gusmão Carneiro ressaltou em seu voto que "a existência de divergências entre ambas - a norma internacional e a de direito interno - não significa propriamente confito, mas traduz ma oposicaa. O plano in , jesta

${ }^{81}$ No que concerne ao Brasil, no Recurso Extraordinário $\mathrm{n}^{\circ} 80.004$, o Ministro Cordeiro Guerra ratificou o entendimento de que a promulgação de um tratado the confere força de lei, mas não constitucional. Vicente Marotta Rangel, em excelente artigo, já em 1967 confirmava esta orientação ("Os Conflitos entre o Direito Interno e os Tratados Internacionais" in Boletim da Sociedade Brasileira de Direito Nacional, $\mathrm{n}^{\circ} 45$ e 46, JanDez 1967, p. 63).

Revista da Faculdade de Direito da UFRGS, v. 21, Março/2002 corrente que sustenta a supremacia do Direito interno perante o Direito internacional vem perdendo espaço ${ }^{82}$. No influxo dos movimentos de integração, com um aumento constante do número de acordos internacionais e com a participação cada vez mais freqüente dos Estados em organismos internacionais, passouse a atribuir às normas internas e às internacionais posição equivalente dentro dos ordenamentos internos.

No Brasil, diante do silêncio da Constituição Federal coube à jurisprudência resolver a questão. E o Supremo Tribunal Federal acatou o entendimento da equivalência, com prevalência em todos os casos da Carta constitucional ${ }^{83}$

Agora, parece-nos que a tendência seria no sentido do reconhecer-se a superioridade dos tratados internacionais perante as leis internas, sejam eles anteriores ou posteriores às mesmas. Assim, o que já era claro para o Direito internacional positivo e para os tribunais internacionais, tenderia agora a ser também aceito pelos ordenamentos internos. Isto, contudo, só o tempo confirmará.

\section{CONCLUSÃO}

A partir dos elementos analisados ao longo de nosso estudo, observamos que o Direito internacional já existia de forma embrionária na Antigüidade. Com o seu desenvolvimento ao longo dos séculos confirmaram-se a sua necessidade e a sua utilidade. De limitado que foi em seu período clássico, o Direito internacional teve então gradativamente ampliados seus sujeitos e suas fontes e expandido seu objeto.

No decorrer da análise feita, constatamos também a insubsistência dos argumentos daqueles que negaram caráter jurídico ao Direito internacional e que tiveram de silenciar-se diante da realidade. Quanto a esta questão, acompanhamos a concepção de Kelsen e Verdross, os quais atestam este caráter jurídico do Direito internacional, ao mesmo tempo em que defendem a concepção monista, ou seja, a existência de um sistema jurídico composto pelo Direito internacional e pelos inúmeros Direitos internos.

Neste sentido, não nos parece que tenham razão aqueles que dizem ser superado ou mesmo irrelevante o debate estabelecido entre monistas e dualistas. Afinal, caso ele tivesse sido efetivamente superado, não assistiríamos ainda hoje o constante exercício doutrinário de enquadrar numa ou noutra corrente este ou aquele ordenamento interno. Da mesma forma, uma disputa que tanto contribuiu para o desenvolvimento do Direito internacional e da ciência jurídica não pode ser subestimada.

De outra parte, não podemos deixar de perceber que tratados internacionais são firmados com cada vez mais freqüência, nem que temas que eram considerados exclusivos do Direito interno, foram ganhando paulatinamente foro internacional. Com isto, adquiriram relevo as questões da relação entre as normas internacionais com as normas internas e das formas por meio das quais são

82 Neste sentido, VIGNALI, Heber Arbuet \& ARRIGHI, Jean Michel, op. cit., p. 420, e FRANCESCHINI, José Carlos de Magalhães, op. cit., p. 420.

${ }^{83}$ Mais recentemente, o Supremo Tribunal Federal enfrentou a questão no julgamento dos Hábeas Corpus $\mathrm{n}^{\circ}$ 72.131, $\mathrm{n}^{\circ} 73.044-2 / \mathrm{SP}$ e $\mathrm{n}^{\circ} 74.383$, entre outros. Não obstante, há decisões em que se entendeu em sentido contrário, admitindo-se a derrogação de disposição constitucional por instrumentos internacionais (v.g. Habeas Corpus $n^{\circ} 197042666$, julgado pelo extinto Tribunal de Alçada do Rio Grande do Sul). 
solucionados os conflitos que entre elas se estabelecem.

Finalmente, diante de tudo quanto pudemos analisar, reafirmamos a importância e a atualidade do tema proposto. Com certeza, o intercâmbio cultural e econômico não é uma peculiaridade de nosso mundo atual, fazendose presente desde os mais remotos tempos. Todavia, os modernos meios de comunicação e de transporte o intensificaram em proporções assombrosas. E isto impõe desafios cada vez maiores para o Direito e para seus operadores. Cumpre, pois, que os enfrentemos e, para tanto, devemos conhecer e aperfeiçoar os instrumentos de que dispomos, dentre eles, o Direito internacional ${ }^{84}$.

\section{BIBLIOGRAFIA}

ACCIOLY, Hildebrando. Tratado de Direito Internacional Público. Rio de Janeiro, 1956, v. I.

ANZILOTTI, Dionisio. Cours de Droit International. Paris: Recueil Sirey, 1929, v. I.

ARRIGHI, Jean Michel. "La Solución de Controversias entre Normas Internacionales y Normas Nacionales (con especial referencia al MERCOSUR)" in Boletim da Sociedade Brasileira de Direito Nacional, nº 45 e 46, Janeiro-Junho 1994. pp. 39-66.

BAPTISTA, Luiz Olavo. "Inserção dos Tratados no Direito Brasileiro" in Revista de Informação Legislativa, $\mathrm{n}^{\circ} 132$. OutubroDezembro 1996, pp. 71-80.

BARROS, José Fernando Cedeño de. "Monismo e Dualismo - Tratados Internacionais e o Direito Interno Brasileiro à Luz da Jurisprudência do Supremo Tribunal Federal - Interpretação do Art. 98 do CTN" in Cadernos de Direito Tributário, $n^{\circ} 27$, pp. 79-94.

BITTAR Filho, Carlos Alberto. "Evolução Histórica do Direito Internacional" in Revista de Informação Legislativa, $\mathrm{n}^{\circ} 115$, Julho-Setembro 1992, pp. 381-398.

BOBBIO, Norberto. O Positivismo JurídicoLições de Filosofia do Direito. São Paulo, Ícone, 1995.

CAMINHA, Maria do Carmo Puccini. "Os Juízes diante dos Tratados Internacionais de Proteção aos Direitos do Homem" in Revista dos Tribunais, $\mathrm{n}^{\circ}$ 761, Março 1999 pp. 151-157.

COMBACAU, Jean. "Le Droit Internacional: Bric-à-Brac ou Système?" in Archives de Philosophie du Droit - Tome 31. Paris: Sirey, 1986, pp. 85-105.

FERREIRA, Aurélio Buarque de Holanda. Novo Dicionário da Língua Portuguesa. Rio de Janeiro: Nova Fronteira, 1986.

RANCESCHINI, José Inácio G.. "Conflito entre os Tratados Internacionais e as Normas de Direito Interno que lhes forem posteriores" in Revista dos Tribunais, $\mathrm{n}^{\circ} 556$, Fevereiro 1982,pp. 28-36.

FILIPPI, Rejane Brasil. "Conflito entre Tratado Internacional e Lei Interna Posterior no Tempo" in Revista da Associação dos Juizes do Rio Grande do Sul, $\mathrm{n}^{\circ} 34$, Julho 1985, pp. 226-235.
GALINDO, George Rodrigo Bandeira. "Reforma Constitucional e o Problema da Superioridade Hierárquica dos Tratados Frente às Leis Internas" in Cadernos de Direito Constitucional e Ciência Política, $\mathrm{n}^{\circ}$ 27, Abril-Junho 1999, pp. 143-153.

GIRAUD, Emile. "Le Droit International Public et la Politique" in Recueil des Cours, Tome 110. Holanda: A.W. Sijthoff, 1966.

GOLDSCHMIDT, Werner. Introducción Filosófica al Derecho. Buenos Aires: Depalma, 1987.

GOMES, Luiz Flávio. “A Questão da Obrigatoriedade dos Tratados e Convenções no Brasil (Particular Enfoque da Convenção Americana sobre Direitos Humanos)" in Revista dos Tribunais, $\mathrm{n}^{\circ} 710$, Dezembro 1994, pp. 21-31.

KELSEN, Hans. Teoria Pura do Direito. São Paulo: Martins Fontes, 1999.

LACHS, Manfred. 'Le Droit International a L'Aube du XXI Siécle" in Revue Générale de Droit International Public, Tome 96. Paris: Editions A. Pedone, $1992\left(\mathrm{n}^{\circ} 3\right)$, pp. 529-550.

MAGALHÃES, José Carlos de. "Dos Fatores de Transformação do Direito Internacional" in Revista dos Tribunais, $\mathrm{n}^{\circ} 717$, Julho 1995, pp. 314-319.
MELLO, Celso D. de Albuquerque. Curso de Direito Internacional Público. Rio de Janeiro: Livraria Freitas Bastos, $2^{\mathrm{a}}$ edição.

MONACO, Riccardo. "Cours Général sur des Príncipes de Droit International Public" in Recueil des Cours, Tome 125. Holanda: A.W. Sijthoff, 1970.

MORAES, Alexandre de. Direito Constitucional. São Paulo: Atlas, 2001.

RANGEL, Vicente Marotta. “'Os Conflitos entre o Direito Interno e os Tratados Internacionais" in Boletim da Sociedade Brasileira de Direito Nacional, ${ }^{\circ} 45$ e 46, Jan-Dez 1967, pp. 29-64.

VERDROSS, Alfred. Derecho Internacional Público. Madrid: Aguilar, 1957.

VIGNALI, Heber Arbuet \& ARRIGHI, Jean Michel. "Os Vínculos entre o Direito Internacional Público e os Sistemas Internos" in Revista de Informação Legislativa, $\mathrm{n}^{\circ}$ 115, Julho-Setembro 1992, pp.413-420.

VILLEY, Michel. “Considérations Intempestives sur le Droit des Gens" in Archives de Philosophie du Droit - Tome 32. Paris: Sirey, 1987, pp. 13-21.

${ }^{84}$ Como bem aponta Manfred Lachs, ex-presidente da Corte Internacional de Justiça, "Les juristes ne sont pas les moteurs de l'histoire mais nous pouvons ouvrir la porte du vingt-et-unième convaincu que la possée galopante des événements souligne la grande importance du droit international et exige son développement dans tous les domaines de la vie, autrement les relations internationales mêmes quotidiennes risquent de devenir impossible" ("Le Droit International a L'Aube du XXI" Siècle" in Revue Générale de Droit International Public, Tome 96 Paris: Editions A. Pedone, $1992\left(\mathrm{n}^{\circ} 3\right)$, p. 549)

Revista da Faculdade de Direito da UFRGS, v. 21, Março/2002 